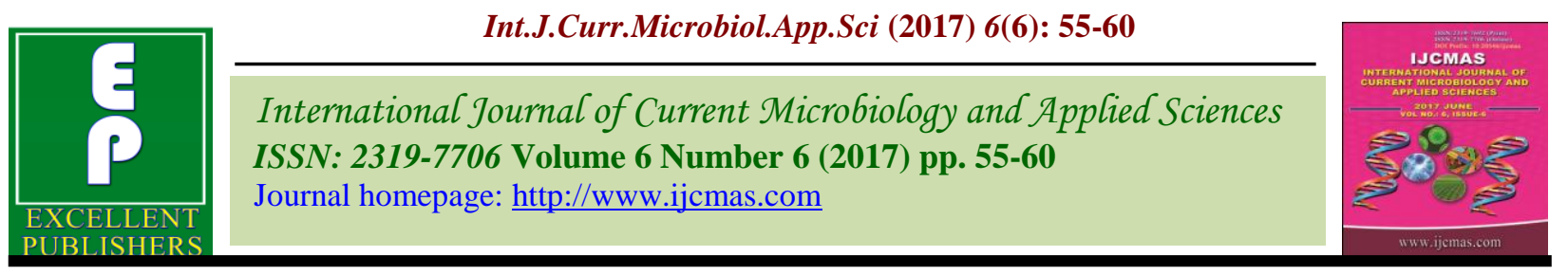

Original Research Article

https://doi.org/10.20546/ijcmas.2017.606.006

\title{
Effect of Graded Doses of Sulphur and Boron on Yield Attributes and Nutrient Uptake by Chickpea
}

\author{
D.C. Kala ${ }^{1 *}$, R.N. Dixit ${ }^{2}$, Shiv Singh Meena, Gangadhar Nanda ${ }^{3}$ and Ritesh Kumar Pal ${ }^{4}$ \\ ${ }^{1}$ Department of Soil Science, G.B. Pant University of Agriculture and Technology, \\ Pantnagar, Uttarakhand-263 145, India \\ ${ }^{2}$ Department of Soil Science and Agricultural Chemistry, C. S. Azad University of Agriculture \\ and Technology, Kanpur-208 002, India \\ ${ }^{3}$ Department of Agronomy, G.B. Pant University of Agriculture and Technology, \\ Pantnagar, Uttarakhand-263 145, India \\ ${ }^{4}$ Department of Agronomy, SGRR (PG), College, Dehradun, Uttarakhand- 248 001, India \\ *Corresponding author
}

\section{A B S T R A C T}

Keywords

S levels, B levels, yield attributes, nutrient uptake, chickpea

Article Info

Accepted:

04 May 2017

Available Online:

10 June 2017
A factorial experiment in randomized complete block design involving three Sulphur levels i.e. 0,20 and $40 \mathrm{~kg} \mathrm{~S} h a^{-1}$ and three levels of Boron viz. $0,0.5$ and $1 \mathrm{~kg} \mathrm{~B} \mathrm{ha}{ }^{-1}$ with nine treatment combinations with four replications was carried out during rabi season, 2012-13 to evaluate the effect of graded doses of Sulphur and Boron on yield attributes and nutrient uptake by chickpea. Results revealed that increasing $\mathrm{S}$ levels up to $40 \mathrm{~kg} \mathrm{ha}^{-1}$ significantly increased yield attributes and seed yield of chickpea. Seed, stover and total uptake of N, P, K, S and B increased significantly up to $40 \mathrm{~kg} \mathrm{~S} \mathrm{ha}^{-1}$. Yield attributes increased with graded doses of B but seed yield increased significantly with increasing doses of Boron. Maximum $\mathrm{N}, \mathrm{P}, \mathrm{K}, \mathrm{S}$ and B uptake by seed and stover and their total uptake was observed with application of $1.0 \mathrm{~kg} \mathrm{~B} \mathrm{ha}^{-1}$ which was significantly higher than its lower doses.

\section{Introduction}

Pulse production in India is about 19.27 million tonnes with area under cultivation of around 25.23 million hectare and an average productivity of nearly 0.76 tonnes $\mathrm{ha}^{-1}$ (Anonymous, 2014). Pulse productivity of India is very much lesser than the other producing countries. In India, $48 \%$ of total pulse production is contributed by chickpea, signifying its importance in Indian agricultural production. Optimization of macro- and micro- nutrient application will enhance the productivity of chickpea. Sulphur is considered as the fourth major nutrient after $\mathrm{N}, \mathrm{P}$ and $\mathrm{K}$. It is basically required for synthesis of proteins, especially S-containing amino acid i.e. methionine, cystine and cysteine and as a constituent of vitamins (thiamine and biotin) and other biologically active compounds like lipoic acid, acetyl coenzyme-A, ferredoxin and glutathione. 
Moreover, sulphur deficiency adversely affects the chlorophyll synthesis. Beneficial effect of sulphur attributed to increase the number of nodules/plant resulting from improved root growth (Lange et al., 1994). Boron (B) plays important role in cell-wall synthesis, sugar transport, cell division, differentiation, membrane functioning, root elongation, regulation of plant hormone level and generative growth in plants. Deficiency and toxicity of sulphur and boron may lead to affect the performance of chickpea. Taking this in view, the present investigation was undertaken to examine the appropriate doses of application for sulphur and boron in chickpea under central plains of Uttar Pradesh, India.

\section{Materials and Methods}

A field experiment was conducted during rabi season of 2012-13 at pot culture house of the Department of Soil Science and Agricultural Chemistry, C. S. Azad University of Agriculture and Technology, Kanpur with the coordinates $26.46^{\circ}$ North and $80.35^{\circ}$ East at the elevation of 125.9 meters above the mean sea level with mean annual rainfall of about $816.0 \mathrm{~mm}$. Initial physio-chemical characteristics and fertility status of experimental field was observed by the soil samples collected randomly from the each micro plot to the depth of $0-15 \mathrm{~cm}$ with the help of soil auger prior to crop cultivation. Soil samples collected were analyzed for mechanical and chemical analysis, treatment wise. Soil $\mathrm{pH}(1: 2.5)$ of experimental site was found to be vary from 8.10 to 8.25 while EC0.26 to $0.30 \mathrm{dS} \mathrm{m}{ }^{-1}$, organic carbon- 0.36 to $0.38 \%$, available nitrogen $\left(\mathrm{kg} \mathrm{ha}^{-1}\right)-178$ to 180 , available phosphorus $\left(\mathrm{kg} \mathrm{ha}^{-1}\right)-10.32$ to 10.90, available potassium ( $\left.\mathrm{kg} \mathrm{ha}^{-1}\right)-160$ to 165, available sulphur ( $\left.\mathrm{mg} \mathrm{kg}^{-1}\right)-6.50$ to 6.70 and available boron ( $\left.\mathrm{mg} \mathrm{kg}^{-1}\right)-0.450$ to 0.480 . Soil samples analyzed was found to be of loamy texture. Three levels of sulphur $(0,20$ and $\left.40 \mathrm{~kg} \mathrm{Sha}^{-1}\right)$ and three levels of Boron (0, 0.5 and $1 \mathrm{~kg} \mathrm{~B} \mathrm{ha}^{-1}$ ) with a total of nine treatment combinations viz. T1- (SOB0) $0 \mathrm{~kg}$ $\mathrm{S} \mathrm{ha}^{-1}+0 \mathrm{~kg} \mathrm{~B} \mathrm{ha}^{-1}, \mathrm{~T} 2-(\mathrm{S} 1 \mathrm{~B} 0) 20 \mathrm{~kg} \mathrm{~S}^{-1}$ $+0 \mathrm{~kg} \mathrm{~B} \mathrm{ha}^{-1}$, T3- (S2B0) $40 \mathrm{~kg} \mathrm{~S} \mathrm{ha}^{-1}+0 \mathrm{~kg}$ $\mathrm{B} \mathrm{ha}^{-1}$ T4- (S0B1) $0 \mathrm{~kg} \mathrm{~S}^{-1}+0.5 \mathrm{~kg} \mathrm{~B} \mathrm{ha}^{-1}$, T5-(S1B1) $20 \mathrm{~kg} \mathrm{~S} \mathrm{ha}^{-1}+0.5 \mathrm{~kg} \mathrm{~B} \mathrm{ha}^{-1}$, T6(S2B1) $40 \mathrm{~kg} \mathrm{~S} \mathrm{ha}^{-1}+0.5 \mathrm{~kg} \mathrm{~B} \mathrm{ha}^{-1}$, T7(S0B2) $0 \mathrm{~kg} \mathrm{~S} \mathrm{ha}^{-1}+1.0 \mathrm{~kg} \mathrm{~B} \mathrm{ha}^{-1}$, T8(S1B2) $20 \mathrm{~kg} \mathrm{Sha}^{-1}+1.0 \mathrm{~kg} \mathrm{~B} \mathrm{ha}^{-1}$ and T9(S2B2) $40 \mathrm{~kg} \mathrm{~S} \mathrm{ha}^{-1}+1.0 \mathrm{~kg} \mathrm{~B} \mathrm{ha}^{-1}$ were laid out in factorial experiment in randomized complete block design with four replications. Chickpea variety Udai (K-75) was taken as the test crop. The size of each micro plots were $0.374 \mathrm{~m}^{2}$ in the glasshouse. Nitrogen, phosphorus and potash were applied as basal dressing in all plots@20,50 and $20 \mathrm{~kg} \mathrm{ha}^{-1}$, respectively. The sources of fertilizers used were DAP for nitrogen and phosphorous and muriate of potash for potassium, which were applied as basal. Besides these, application of sulphur and boron was also done basally as per the treatments through elemental sulphur and borax, respectively. Total numbers of pods were collected from the sample plant and their pods were weighed for pod weight plant $^{-1}$. After drying and cleaning, a composite sample of seeds were drawn for different treatments and one hundred (100) seeds were counted from each sample and weighed to get the 100 seed weight in gram and seed yield was recorded by standard procedure. Seed and stover samples were analysed for $\mathrm{N}$ content by Kjeldahl's method as described by Piper (1966). Phosphorus by colourimetric method as described by Jackson (1967), Potassium by flame photometer as described by Jackson (1967), Sulphur by turbidimetric method as described by Chesnin and Yien (1950) and Boron by Jackson (1965). Nutrient content (\%) in seed and stover was multiplied with respective seed and stover yield to obtain uptake by seed and stover, respectively. Total nutrient uptake was calculated by adding uptake by seed and 
stover. The data were statistically analyzed by standard method (Chandel, 1975).

\section{Results and Discussion}

\section{Yield attributes and seed yield}

Yield attributes viz., pod weight plant $^{-1}$, weight of 100 seeds and seed yield of chick pea was influenced significantly by different graded doses of Sulphur and Boron (Table 1). With the increments in the doses of sulphur, the value yield attributes and seed yield increased significantly up to the highest level of $40 \mathrm{Kg} \mathrm{S} \mathrm{ha}^{-1}$. Similar results about sulphur were also reported by Scherer and Lange (1996), Shivakumar (2001), Kumar et al.,
(2003), Vishram Ram et al., (2007), Nawange et al., (2011) and Islam (2012).

As regards to boron levels, highest 100 grain weight and pod weight/plant was observed with application of $1.0 \mathrm{~kg} \mathrm{~B} \mathrm{ha}^{-1}$ which was significantly higher than control treatment. However, seed yield increased significantly with successive increase in B levels. This is attributed to lesser flower drop and enhanced pollen growth under higher levels of Boron. Beneficial effect of Boron on flower drop and seed yield was noticed by Guhey et al., (2008) and losses in seed yield under Boron deficiency was observed by Ceyhan et al., (2007) in chickpea.

Table.1 Effect of graded doses of Sulphur and Boron on yield Attributes and seed yield of chickpea

\begin{tabular}{|c|c|c|c|}
\hline Treatments & $\begin{array}{l}100 \text { grain } \\
\text { weight (g) }\end{array}$ & Pod weight plant $^{-1}$ & $\begin{array}{c}\text { Seed yield } \\
\text { (kg/ha) }\end{array}$ \\
\hline \multicolumn{4}{|c|}{ S levels (kg/ha) } \\
\hline 0 & 20.25 & 16.79 & 1403.00 \\
\hline 20 & 21.69 & 18.95 & 1571.33 \\
\hline 40 & 23.08 & 20.98 & 1760.00 \\
\hline SEd & 0.32 & 0.37 & 36.35 \\
\hline $\mathrm{CD}(P=0.05)$ & 0.66 & 0.77 & 75.05 \\
\hline \multicolumn{4}{|c|}{ B levels (kg/ha) } \\
\hline 0 & 21.18 & 17.99 & 1490.66 \\
\hline 0.5 & 21.73 & 19.02 & 1583.33 \\
\hline 1.0 & 22.18 & 19.69 & 1660.33 \\
\hline SEd & 0.32 & 0.37 & 36.35 \\
\hline $\mathrm{CD}(P=0.05)$ & 0.66 & 0.77 & 75.05 \\
\hline Interaction & NS & NS & $\mathrm{NS}$ \\
\hline
\end{tabular}


Table.2 Effect of graded doses of Sulphur and Boron on N, P, K, S and B uptake by seed and stover and their total uptake by chickpea

\begin{tabular}{|c|c|c|c|c|c|c|c|c|c|c|c|c|c|c|c|}
\hline \multirow[t]{2}{*}{ Treatments } & \multicolumn{3}{|c|}{ N uptake $\left(\mathrm{kg} \mathrm{ha}^{-1}\right)$} & \multicolumn{3}{|c|}{ P uptake (kg ha $\left.{ }^{-1}\right)$} & \multicolumn{3}{|c|}{ K uptake $\left(\mathrm{kg} \mathrm{ha}^{-1}\right)$} & \multicolumn{3}{|c|}{ S uptake $\left(\mathrm{kg} \mathrm{ha}^{-1}\right)$} & \multicolumn{3}{|c|}{ B uptake $\left(\mathrm{kg} \mathrm{ha}^{-1}\right)$} \\
\hline & Seed & Stover & Total & Seed & Stover & Total & Seed & Stover & Total & Seed & Stover & Total & Seed & Stover & Total \\
\hline \multicolumn{16}{|c|}{ S levels (kg/ha) } \\
\hline 0 & 44.21 & 31.41 & 75.62 & 17.48 & 6.91 & 24.38 & 7.367 & 25.77 & 33.14 & 9.69 & 3.28 & 12.97 & 72.52 & 60.76 & 133.29 \\
\hline 20 & 50.13 & 38.68 & 88.81 & 21.55 & 9.16 & 30.71 & 9.76 & 31.54 & 41.29 & 11.32 & 4.27 & 15.58 & 87.33 & 73.31 & 160.65 \\
\hline 40 & 56.68 & 47.18 & 103.86 & 26.36 & 10.74 & 37.09 & 12.69 & 35.79 & 48.48 & 13.21 & 5.28 & 18.52 & 101.89 & 86.81 & 188.45 \\
\hline SEd & 0.93 & 0.81 & 1.95 & 0.48 & 0.31 & 0.61 & 0.28 & 0.67 & 0.99 & 0.35 & 0.16 & 0.36 & 0.94 & 0.79 & 2.62 \\
\hline $\mathrm{CD}(P=0.05)$ & 1.92 & 1.66 & 4.03 & 0.99 & 0.63 & 1.26 & 0.57 & 1.39 & 2.04 & 0.72 & 0.33 & 0.75 & 1.94 & 1.62 & 5.42 \\
\hline \multicolumn{16}{|c|}{ B levels (kg/ha) } \\
\hline 0 & 47.35 & 35.67 & 83.02 & 19.85 & 8.18 & 28.03 & 8.82 & 28.74 & 37.56 & 10.62 & 3.88 & 14.50 & 80.61 & 67.51 & 148.12 \\
\hline 0.5 & 50.49 & 39.13 & 89.62 & 21.89 & 8.94 & 30.83 & 9.98 & 31.02 & 41.01 & 11.43 & 4.28 & 15.74 & 87.90 & 73.93 & 161.59 \\
\hline 1.0 & 53.17 & 42.48 & 95.65 & 23.65 & 9.68 & 33.33 & 11.01 & 33.34 & 44.35 & 12.16 & 4.67 & 16.83 & 93.32 & 79.44 & 172.68 \\
\hline SEd & 0.93 & 0.81 & 1.95 & 0.48 & 0.31 & 0.61 & 0.28 & 0.67 & 0.99 & 0.35 & 0.16 & 0.36 & 0.94 & 0.79 & 2.62 \\
\hline $\mathrm{CD}(P=0.05)$ & 1.92 & 1.66 & 4.03 & 0.99 & 0.63 & 1.26 & 0.57 & 1.39 & 2.04 & 0.72 & 0.33 & 0.75 & 1.94 & 1.62 & 5.42 \\
\hline Interaction & $\mathrm{NS}$ & NS & NS & NS & NS & NS & NS & NS & NS & $\mathrm{NS}$ & $\mathrm{NS}$ & NS & NS & $\mathrm{NS}$ & NS \\
\hline
\end{tabular}




\section{Nutrient uptake}

$\mathrm{N}, \mathrm{P}, \mathrm{K}, \mathrm{S}$ and $\mathrm{B}$ uptake by seed and stover and their total uptake by chickpea is presented in table 2 shows that the graded doses of Sulphur and Boron caused significant variation in nutrient uptake. Uptake by seed and stover and total nutrient uptake increased with higher doses of nutrient applied. Nutrient uptake viz. N, P, K, S, B by seed and stover and their total uptake increased significantly up to the level of $40 \mathrm{~kg} \mathrm{~S} \mathrm{ha}^{-1}$. Kumar et al., (2003) and Chiaiese et al., (2004) reported about the increment sulphur content in grain and stover of chickpea with the application of sulphur. Application of sulphur results in increased $\mathrm{N}$ fixation (Lange et al., 1994; Scherer and Lange, 1996; Zhao et al., 1999) which might have promoted production of higher amounts of above ground dry matter that could have led to higher acquisition of nutrients ultimately resulted in higher nutrient content in grain and stover. Higher nutrient content coupled with higher seed and stover yield led to higher nutrient uptake.

Boron application up to the level $1.0 \mathrm{~kg} \mathrm{ha}^{-1}$ was found to increase nutrient uptake by seed and stover and their total uptake in chickpea over control. The highest dose of boron applied in the experiment was found to increase the nutrient uptake by seed and stover and their total uptake significantly. Guhey et al., (2008) reported positive effect of Boron on chlorophyll content which may be responsible for the increase in the nutrient content and uptake by plant with the higher growth characters. Yakubu et al., (2010) also reported about the beneficial effect of boron in nitrogen uptake in legumes. So, increased chlorophyll content could have resulted in higher photosynthates and biomass production which would have been efficiently distributed to the roots for its development and for supplying energy for nutrient uptake.
$\mathrm{S}$ and $\mathrm{B}$ fertilization have a pivotal role in enhancing yield attributing characters and nutrient uptake performance in chickpea. Application of $40 \mathrm{~kg} \mathrm{ha}^{-1}$ of $\mathrm{S}$ and $1.0 \mathrm{~kg} \mathrm{~B}$ $\mathrm{ha}^{-1}$ proved to increase yield attributes and nutrient uptake by chickpea under central plains of Uttar Pradesh, India.

\section{References}

Anonymous. 2014. Agricultural Statistics at a Glance 2014. Directorate of Economics and Statistics, Department of Agriculture and Cooperation, Ministry of Agriculture, Government of India. Pp. 92.

Ceyhan, E., Onder, M., Harmankaya, M., Hamurcu, M. and Gezgin, S. 2007. Response of chickpea cultivars to application of boron in boron-deficient calcareous soils. Commun. Soil Sci. Plant Anal., 38(17/18): 2381-2399.

Chandel, S.R.S. 1975. A Hand book of Agricultural statistics Achal Prakashan Mandir, Kanpur, B-79-113.

Chesnin, L. and Yien, C.H. 1950. Turbidimetric determination of available sulphate. Soil Sci. Am. Proc., 15: 149-151.

Chiaiese, P., Ohkama-Ohtsu, N., Molvig, L., Godfree, R., Dove, H., Hocart, C., Fujiwara, T., Higgins, T. J. V. and Tabe, L. 2004. Sulphur and nitrogen nutrition influence the response of chickpea seeds to an added, transgenic sink for organic sulphur. J. Exp. Bot., 55(404): 1889-1901.

Guhey Arti, Sha, R. A., Khan, M. I. and Kuruwanshi, V.B. 2008. Effect of boron application on germination nodulation, chlorophyll content, flower drop and seed yield in chickpea (Cicer arietinum L.). Adv. Plant Sci., 21(1): 333-335.

Islam, M. 2012. The effect of different rates and forms of sulfur on seed yield and 
micronutrient uptake by chickpea. Plant, Soil Env., 58(9): 399-404.

Jackson, M.L. 1967. Soil chemical Analysis. Prentice Hall of Private Ltd., New Delhi.

Kumar Narendra, Khangarot, S. S. and Meena, R. P. 2003. Effect of sulphur and plant growth-regulators on yield and quality parameters of chickpea (Cicer arietinum L.). Ann. Agric. Res., 24(2): 434-436.

Lange, A., Scherer, H. W. and Werner, W. 1994. Influence of sulfur supply on biological nitrogen fixation in legumes. [German] Vortrage zum Generalthema des 106. VDLUFA-Kongresses vom 19.-24.

Nawange, D. D., Yadav, A. S. and Singh, R. V. 2011. Effect of phosphorus and sulphur application on growth, yield attributes and yield of chickpea (Cicer arietinum L). Legume Res., 34(1):48-50.

Piper, C.S. 1966. Soil and Plant Analysis, University Adelaide. Australia.

Scherer, H. W. and Lange, A. 1996. N2 fixation and growth of legumes as affected by sulphur fertilization. Biol. Fertil. Soils, 23(4): 449-453.

Shivakumar, B. G. 2001. Performance of chickpea (Cicer arietinum) varieties as influenced by sulphur with and without phosphorus. Indian J. Agron., 46(2): 273-276.

Vishram Ram, Dohare, A. P. S. and Yadav, P. K. 2007. Effect of phosphorus and sulphur levels on growth and yield of chickpea (Cicer arietinum L.) in rainfed area under bundelkhand conditions. Plant Arch., 7(1): 257-259.

Yakubu, H., Kwari, J. D. and Tekwa, J. A. 2010. Nodulation and N2-fixation by grain legumes as affected by boron fertilizer in Sudano-Sahelian zone of North-eastern Nigeria. Am.-Eur. J. Agricult. Environ. Sci., 8(5): 514-519.

Zhao, F. J., Wood, A. P. and McGrath, S. P. 1999. Effects of sulphur nutrition on growth and nitrogen fixation of pea (Pisum sativum L.). Plant Soil, 212(2): 209-219.

\section{How to cite this article:}

Kala D.C., R.N. Dixit, Shiv Singh Meena, Gangadhar Nanda and Ritesh Kumar Pal. 2017. Effect of Graded Doses of Sulphur and Boron on Yield Attributes and Nutrient Uptake by Chickpea. Int.J.Curr.Microbiol.App.Sci. 6(6): 55-60. doi: https://doi.org/10.20546/ijcmas.2017.606.006 